\title{
DNA Damage in Buccal Mucosa Cells of Pre-School Children Exposed to High Levels of Urban Air Pollutants
}

\author{
Elisabetta Ceretti ${ }^{1}$, Donatella Feretti ${ }^{1 *}$, Gaia C. V. Viola ${ }^{1}$, Ilaria Zerbini ${ }^{1}$, Rosa M. Limina ${ }^{1}$, Claudia Zani ${ }^{1}$, \\ Michela Capelli ${ }^{2}$, Rossella Lamera ${ }^{2}$, Francesco Donato ${ }^{1}$, Umberto Gelatti ${ }^{1}$
}

1 Unit of Hygiene, Epidemiology and Public Health, Department of Medical and Surgical Specialities, Radiological Sciences and Public Health, University of Brescia, Brescia, Italy, 2 Post-Graduate School of Public Health, University of Brescia, Brescia, Italy

\begin{abstract}
Air pollution has been recognized as a human carcinogen. Children living in urban areas are a high-risk group, because genetic damage occurring early in life is considered able to increase the risk of carcinogenesis in adulthood. This study aimed to investigate micronuclei (MN) frequency, as a biomarker of DNA damage, in exfoliated buccal cells of pre-school children living in a town with high levels of air pollution. A sample of healthy 3-6-year-old children living in Brescia, Northern Italy, was investigated. A sample of the children's buccal mucosa cells was collected during the winter months in 2012 and 2013. DNA damage was investigated using the MN test. Children's exposure to urban air pollution was evaluated by means of a questionnaire filled in by their parents that included items on various possible sources of indoor and outdoor pollution, and the concentration of fine particulate matter (PM10, PM2.5) and $\mathrm{NO}_{2}$ in the 1-3 weeks preceding biological sample collection. 181 children (mean age \pm SD: $4.3 \pm 0.9$ years) were investigated. The mean \pm SD MN frequency was $0.29 \pm 0.13 \%$. A weak, though statistically significant, association of $\mathrm{MN}$ with concentration of air pollutants (PM10, PM2.5 and $\mathrm{NO}_{2}$ ) was found, whereas no association was apparent between MN frequency and the indoor and outdoor exposure variables investigated via the questionnaire. This study showed a high MN frequency in children living in a town with heavy air pollution in winter, higher than usually found among children living in areas with low or medium-high levels of air pollution.
\end{abstract}

Citation: Ceretti E, Feretti D, Viola GCV, Zerbini I, Limina RM, et al. (2014) DNA Damage in Buccal Mucosa Cells of Pre-School Children Exposed to High Levels of Urban Air Pollutants. PLoS ONE 9(5): e96524. doi:10.1371/journal.pone.0096524

Editor: Susanna Esposito, Fondazione IRCCS Ca' Granda Ospedale Maggiore Policlinico, Università degli Studi di Milano, Italy

Received December 24, 2013; Accepted April 8, 2014; Published May 2, 2014

Copyright: (c) 2014 Ceretti et al. This is an open-access article distributed under the terms of the Creative Commons Attribution License, which permits unrestricted use, distribution, and reproduction in any medium, provided the original author and source are credited.

Funding: The study was funded by the Q-TECH Research and Study Centre (Quality and Technology Assessment, Governance and Communication Strategies in Health Systems), University of Brescia. The Lombardy Regional Authority provided a three-year research grant under agreements with the university for the promotion of research in the Lombardy region. The funders had no role in study design, data collection and analysis, decision to publish, or preparation of the manuscript.

Competing Interests: The authors have declared that no competing interests exist.

*E-mail: feretti@med.unibs.it

\section{Introduction}

Air pollution is a global health problem, particularly in urban areas. Close to $90 \%$ of European citizens residing in urban areas are exposed to air pollution exceeding EU limit values (Air Quality Directive 2008/50/EC) and WHO guideline levels [1-3].

Several epidemiologic studies have demonstrated the association between air pollution exposure, especially to particulate matter, and mortality and morbidity in humans [4-8].

The finest fractions of particulate matter (PM2.5 and less) play a major role in causing chronic diseases because they are retained in the alveolar regions of the lungs and diffuse into the blood stream, inducing inflammation, oxidative stress, and blood coagulation $[9,10]$. Extracts of urban air particles can induce cancer in animals $[11,12]$ and are mutagenic in bacteria, plant and mammalian cells in in-vitro tests [13-17]. In-vivo mutagenicity tests have been performed on humans as well. The micronuclei $(\mathrm{MN})$ formation has been used as an indicator of chromosome damage, induced by substances that cause chromosome breakage (clastogens) as well as by agents that affect the spindle apparatus (aneugens) [18]. Other nuclear anomalies were investigated as biomarkers of DNA damage and cell death, which may be useful for a more comprehensive assessment of genotoxic damage [19-22].
An increase in cancer risk has been observed in the presence of a high level of chromosomal aberrations and micronuclei in several studies [23-26]. This biomarker can be investigated in various organs, tissues and body fluids, such as leukocytes or lymphocytes in peripheral blood, though cells derived from target tissues are considered more appropriate. In particular, exfoliated buccal and nasal cells have been used in the biological monitoring of people exposed to airborne pollutants as they are representative of epithelial respiratory tract cells and are easier to collect than those of other respiratory organs [21,27-29].

An increase of micronuclei in leukocytes in peripheral blood has been observed in people exposed to urban air pollutants [30-36] and a strong correlation of MN frequency in buccal exfoliated cells and peripheral lymphocytes has been found $[37,38]$.

Children are a high-risk group in terms of the health effects of air pollution [2,5,39-42]. Some studies suggest that early exposure during childhood can play an important role in the development of chronic diseases in adulthood: the earlier the exposure, the greater the risk of chronic disease, including cancer [43].

Few studies have considered genetic damage in mucosa buccal cells as MN frequency in cells of children exposed to air pollution, and they only involved a small number of subjects showing cytogenetic damage in children or young adults living in polluted 
Table 1. Micronuclei $(\mathrm{MN})$ frequencies observed in buccal mucosa cells of children according to socio-demographic features and exposure variables $(\mathrm{N}=181)$.

\begin{tabular}{|c|c|c|}
\hline Subjects and demographic features & N (\%) & $\%$ MN $($ Mean \pm SD $)$ \\
\hline \multicolumn{3}{|l|}{ Sex } \\
\hline M & $103(56.9)$ & $0.30 \pm 0.13$ \\
\hline $\mathrm{F}$ & $78(43.1)$ & $0.29 \pm 0.13$ \\
\hline \multicolumn{3}{|l|}{ Children's age } \\
\hline 3 years & $34(18.8)$ & $0.31 \pm 0.16$ \\
\hline 4 years & 59 (32.6) & $0.28 \pm 0.13$ \\
\hline $5-6$ years & $88(48.6)$ & $0.29 \pm 0.12$ \\
\hline \multicolumn{3}{|l|}{ Parents' education (at least one parent) } \\
\hline Primary school or less & $19(10.5)$ & $0.28 \pm 0.12$ \\
\hline Secondary school & $53(29.3)$ & $0.32 \pm 0.16$ \\
\hline College or university & $109(60.2)$ & $0.28 \pm 0.12$ \\
\hline \multicolumn{3}{|l|}{ Home characteristics } \\
\hline \multicolumn{3}{|l|}{ Traffic in the area } \\
\hline Heavy & 97 (53.6) & $0.31 \pm 0.14$ \\
\hline Moderate & $59(32.6)$ & $0.28 \pm 0.13$ \\
\hline Very light & $25(13.8)$ & $0.25 \pm 0.08$ \\
\hline \multicolumn{3}{|l|}{ Truck traffic in the area } \\
\hline Heavy & $31(17.1)$ & $0.30 \pm 0.12$ \\
\hline Moderate & $67(37.0)$ & $0.31 \pm 0.17$ \\
\hline Very light & $82(45.3)$ & $0.27 \pm 0.09$ \\
\hline \multicolumn{3}{|l|}{ Indoor exposure } \\
\hline Gas stove in home & $61(33.7)$ & $0.28 \pm 0.11$ \\
\hline Fireplace in home & $37(20.4)$ & $0.28 \pm 0.11$ \\
\hline Presence of smokers in home & $28(15.5)$ & $0.30 \pm 0.18$ \\
\hline \multicolumn{3}{|l|}{ School characteristics } \\
\hline \multicolumn{3}{|l|}{ Traffic in the area } \\
\hline Heavy & $102(56.4)$ & $0.31 \pm 0.15$ \\
\hline Moderate & $68(37.6)$ & $0.27 \pm 0.09$ \\
\hline Very light & $10(5.5)$ & $0.29 \pm 0.15$ \\
\hline \multicolumn{3}{|l|}{ Truck traffic in the area } \\
\hline Heavy & $27(14.9)$ & $0.33 \pm 0.19$ \\
\hline Moderate & $80(44.2)$ & $0.29 \pm 0.12$ \\
\hline Very light & $72(39.8)$ & $0.28 \pm 0.12$ \\
\hline \multicolumn{3}{|l|}{ Child's habits } \\
\hline \multicolumn{3}{|l|}{ Plays outdoors } \\
\hline Less than 1 hour & $78(43.1)$ & $0.31 \pm 0.16$ \\
\hline More than 1 hour but less than 3 hours & $67(37.0)$ & $0.28 \pm 0.10$ \\
\hline 3 hours or more & $35(19.3)$ & $0.28 \pm 0.10$ \\
\hline \multicolumn{3}{|c|}{ Remains in the kitchen while meals are cooked } \\
\hline Never & $24(13.3)$ & $0.29 \pm 0.13$ \\
\hline Sometimes & $119(65.8)$ & $0.30 \pm 0.14$ \\
\hline Often/always & $37(20.4)$ & $0.27 \pm 0.09$ \\
\hline \multicolumn{3}{|l|}{ Consumes fried/grilled/smoked food } \\
\hline Never & $5(2.8)$ & $0.36 \pm 0.17$ \\
\hline More than once per month & $123(68.0)$ & $0.28 \pm 0.14$ \\
\hline \multicolumn{3}{|l|}{ Parents' smoking habits } \\
\hline Neither parent smoke & $118(65.2)$ & $0.29 \pm 0.12$ \\
\hline Mother smoked during pregnancy & $40(22.1)$ & $0.29 \pm 0.14$ \\
\hline Mother smokes & $30(16.6)$ & $0.29 \pm 0.15$ \\
\hline
\end{tabular}


Table 1. Cont.

\begin{tabular}{lll}
\hline & & \\
\hline Subjects and demographic features & N (\%) & \% MN (Mean \pm SD) \\
\hline Father smoke & $49(27.1)$ & $0.30 \pm 0.17$ \\
Both parents smokers & $42(23.2)$ & $0.29 \pm 0.15$ \\
\hline doi:10.1371/journal.pone.0096524.t001 & &
\end{tabular}

areas with a high concentration of PM or oxidant pollutants [33,44-47].

The aim of this study was to investigate MN frequency, as a biomarker of DNA damage, in exfoliated buccal cells of pre-school children living in a town with high levels of air pollution during the winter season, when the highest levels of particulate matter and other pollutants are usually found.

\section{Materials and Methods}

\section{Study design}

This study is part of the RESPIRA study (Italian acronym for Rischio ESPosizione Inquinamento aRia Atmosferica), a molecular epidemiology cross-sectional study aiming to assess the presence of MN frequency in pre-school children living in Brescia, a highly polluted town in Northern Italy, located in the Po Valley, one of the most highly polluted areas of Europe. The children were recruited in 6 schools located in different areas of the town. The study enrolled children aged 3-6 years, born in Italy to European parents, without malignant tumours, who had not undergone radiotherapy or chemotherapy in the previous 12 months or X-rays in the previous 3 months.

The presence of $\mathrm{MN}$ and other nuclear anomalies were investigated in buccal mucosa cells taken from the children.

The biological samples were collected during two consecutive winter seasons (2012 and 2013) since the highest values of PM10 and PM2.5 in Brescia are usually observed in the winter months. The project was approved by the Ethics Committee of Local Unit Health of Brescia (Comitato Etico dell'ASL -Azienda Sanitaria Locale- di Brescia). The children's parents provided their written informed consent to participate in this study. All the data collected were treated confidentially in accordance with current Italian legislation (privacy law).

\section{Questionnaire}

The children's parents were interviewed using an ad hoc questionnaire designed to gather information on exposure to air pollutants from both indoor and outdoor sources, including some characteristics of the area of residence (e.g. traffic, factories), parents' smoking habits, and children's respiratory diseases and drug consumption.

\section{Collection of air pollution data}

Chemical data regarding daily concentration of the most commonly measured air pollutants $\left(\mathrm{CO}, \mathrm{NO}_{2}, \mathrm{SO}_{2}\right.$, benzene, $\mathrm{O}_{3}$, PM10 and PM2.5) were retrieved from the freely available ARPA (Regional Agency for Environmental Protection) database to characterize urban air quality.

\section{Collection of biological samples}

All the biological samples were taken during or after a series of days with high levels of PM10, PM2.5 and $\mathrm{NO}_{2}$.

For the collection of buccal mucosa cells, the children rinsed their mouths twice with mineral water. Interdental brushes were used to collect epithelial buccal cells for the micronucleus test, by gently scraping the inside of both cheeks and dipping them into tubes containing $15 \mathrm{ml}$ of PBS (phosphate buffered saline solution) [21]. This method is simple and non-invasive and therefore easily acceptable by both children and parents.

\section{Micronucleus test}

After shaking and removing the brush, the epithelial buccal cells in PBS were centrifuged for 10 minutes at $1100 \mathrm{~g}$ at $4^{\circ} \mathrm{C}$ and resuspended in warm PBS $\left(37^{\circ} \mathrm{C}\right)$. In order to determine whether enough cells had been collected to perform the test, $10 \mu \mathrm{l}$ of cell suspension was applied in a Burker chamber on which the number of cells was scored. The PBS cell suspension was then centrifuged for 4 minutes at $8700 \mathrm{~g}$ and the pellet was re-suspended in $700 \mu \mathrm{l}$ of warm hypotonic solution $\left(\mathrm{KCl} 0.56 \%, 37^{\circ} \mathrm{C}\right)$. After 1 minute, $700 \mu \mathrm{l}$ of cold methanol/acetic acid $\left(14: 1,-20^{\circ} \mathrm{C}\right)$ was added. This fixed suspension was centrifuged for 4 minutes at $8700 \mathrm{~g}$, and the pellet was re-suspended in $40 \mu \mathrm{l}$ of warm PBS and dropped onto two frosted slides, which were dried and stained with Giemsa dye (5 minutes at room temperature). The slides were then washed with distilled water, dried and mounted with Eukitt.

The slides were examined at $1000 \mathrm{X}$ magnification for microscope analysis. Before MN frequency was assessed, cells were divided into two categories: "normal" cells and ones that are considered "abnormal" based on their cytobiological and nuclear features, which are indicative of DNA damage $(\mathrm{MN}$ and nuclear buds), cytokinetic failure (binucleated cells), proliferative potential (basal cells) or cell death (condensed chromatin, karyorrhexis, pyknotic, karyolitic and without nucleus cells), according to the Buccal Micronucleus Cytome (BMCyt) assay [22]. To assess MN, nuclear buds, binucleated and basal cells frequency, at least 2000 "normal" cells per slide (two slides per subject, 4000 cells per subject) were scored by two expert operators with duplicate reading. The results are given as the percentage of cells with MN and buds, and binucleated and basal cells [19,22]. Moreover, condensed chromatin, karyorrhexis, pyknotic, karyolitic, and without nucleus cells were evaluated scoring 2000 total cells per subject, and expressed as percentages.

\section{Statistical analysis}

All the data were processed to investigate the associations between air pollution parameters and MN frequency. As buccal cells have a short life, no more than 3 weeks [22], the associations between frequency of $\mathrm{MN}$ and other biomarkers frequency and air pollutants concentration $\left(\mathrm{CO}, \mathrm{NO}_{2}, \mathrm{SO}_{2}\right.$, benzene, $\mathrm{O}_{3}, \mathrm{PM} 10$ and PM2.5) were analysed using air pollutants mean levels at 0 (sampling day), 1, 2 and 3 weeks before sampling. Both univariate analysis and multivariate analysis (multiple regression, logistic regression) were performed to assess the association investigated, adjusting for confounding factors. Particularly, linear regression with biological parameters as dependent variables and the concentration of air pollutants as independent variables were fitted. In order to improve the interpretation of these findings the coefficients of the linear regression were computed on a $10 \mu \mathrm{g} / \mathrm{m}^{3}$ 


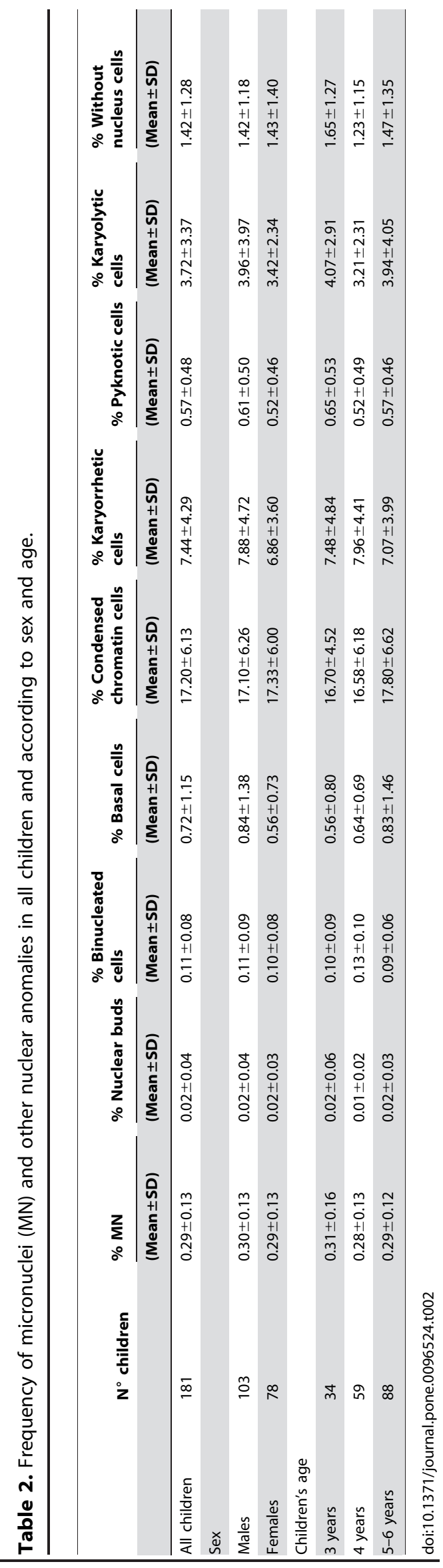

scale of measures of air pollutants. Two-tailed statistical tests were performed, with $0.05 \mathrm{p}$-value as the threshold for rejecting the null hypothesis. All the analyses were performed using the Stata TM 12.0 statistical package (Stata Statistical Software Release 12.0, 2012; Stata Corporation, College Station, Texas, USA).

\section{Results}

A total of 222 children were recruited, of whom 181 (mean age \pm SD: $4.35 \pm 0.84$ years; $56.9 \%$ males) were examined because 41 samples were not eligible for $\mathrm{MN}$ analysis due to an insufficient number of cells collected.

The mean \pm SD MN frequency expressed as a percentage was $0.29 \pm 0.13$ (median 0.28 and range $0.085-0.990$ ).

Table 1 shows the results of the MN analysis, according to children's socio-demographic characteristics and habits, and indoor and outdoor exposure data. No variable was associated with $\mathrm{MN}$ frequency in exfoliated buccal cells.

Table 2 sets out all the biomarkers evaluated in the buccal mucosa cells of children according to children's sex and age. No statistically significant difference was observed according to sex and age for each parameter.

The daily levels of PM10, PM2.5 and $\mathrm{NO}_{2}$ from January to March 2012 and 2013, and biological sampling days are shown in Figure 1. During these months, the concentrations of PM10 and PM2.5 were almost always over the EU limit values for daily means (50 and $25 \mu \mathrm{g} / \mathrm{m}^{3}$, respectively). Likewise, the annual EU limit for $\mathrm{NO}_{2}(40 \mu \mathrm{g} / \mathrm{m} 3)$ was exceeded on all the days. On the contrary, the concentration of $\mathrm{CO}$, ozone, $\mathrm{SO}_{2}$ and benzene remained low throughout the period considered and were always below the EU limit values (data not shown).

The mean MN frequency according to concentrations of PM10, PM2.5 and $\mathrm{NO}_{2}$ on the day of sampling and one, two and three weeks before sampling are shown in Table 3. A fair variation (from $0.21 \%$ to $0.62 \%$ ) was found in $\mathrm{MN}$ frequency from one day to another, without a clear relationship with concentration of air pollutants.

The coefficients of linear regressions of the biological markers on the concentration of PM10, PM2.5 and $\mathrm{NO}_{2}$ on the same day and at 1, 2 and 3 weeks preceding biological sampling computed for $10 \mu \mathrm{g} / \mathrm{m}^{3}$ units of increase are shown in Table 4 . A modest, though statistically significant, increase of the frequency of nuclear anomalies (MN, buds and binucleated cells) and of basal cells for an increase of PM10, PM2.5 and $\mathrm{NO}_{2}$ was found. No clear pattern was evident for the other parameters.

\section{Discussion}

The main finding of this study was a surprisingly high level of $\mathrm{MN}$ frequency in exfoliated buccal cells of pre-school children living in Brescia.

The MN frequency (mean: $0.29 \%$ ) observed in our study was higher than that observed in healthy children "without important exposure" $(0.108 \%)$ as a result of a pooled analysis of 321 children aged up to 9 years [48]. Furthermore, the value observed in children living in Brescia was higher than that shown in adolescents or young adults working in an engine repair workshop (mean age: 15.5 years, MN frequency: 0.07\%) [49] or exposed to ozone air pollution (university students, MN frequency: $0.12 \%$ ) [46]. However, these studies are not comparable to ours due to the different age of the people investigated. Age is in fact one of the most important factors affecting $\mathrm{MN}$ data in both lymphocytes and oral cells, with a progressively increase of $\mathrm{MN}$ with age $[33,36,48,50]$. However, the MN frequency observed in our study was higher than that found in children (aged 6-17) living in the 

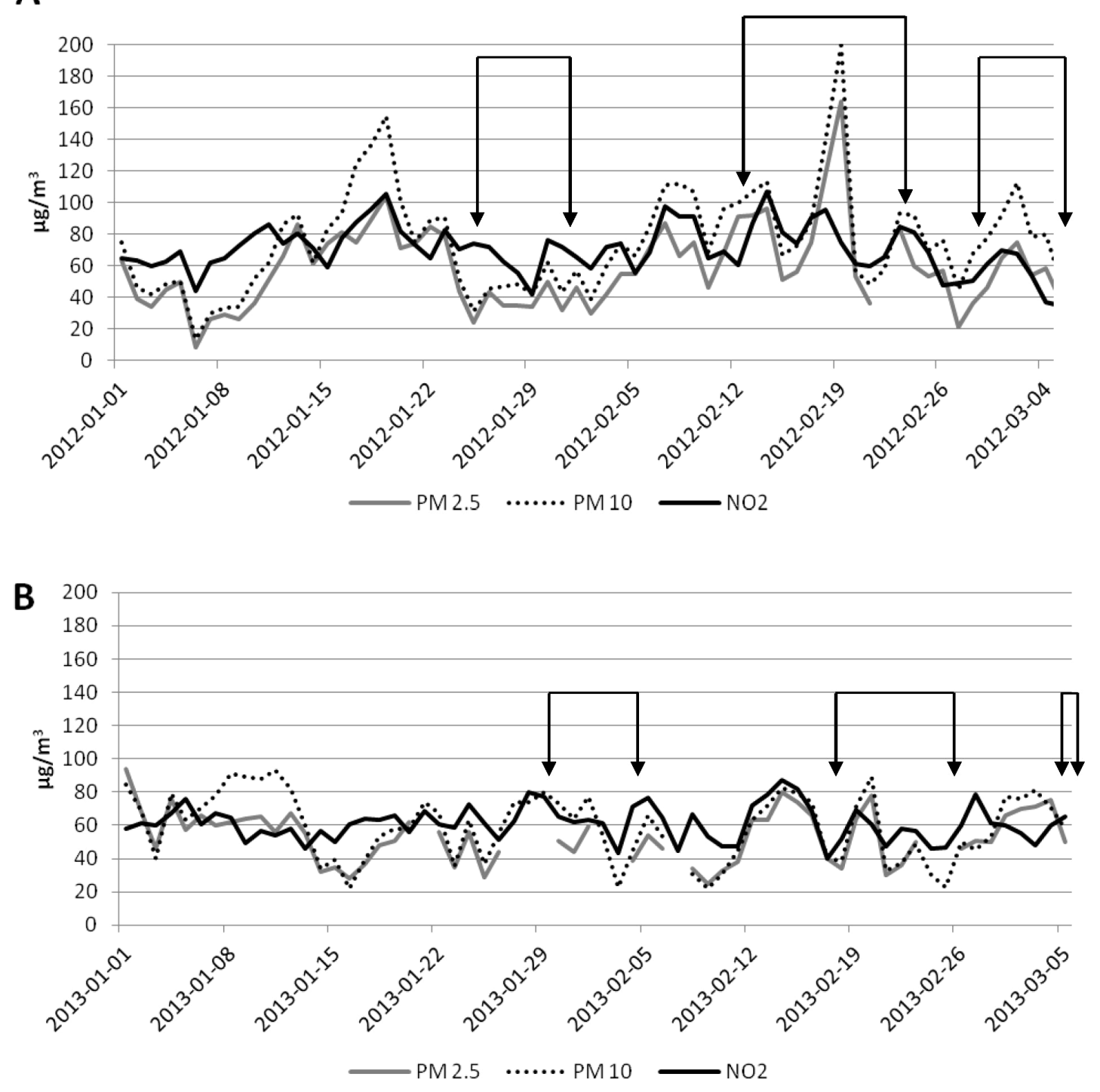

Figure 1. PM10, PM2.5 and $\mathrm{NO}_{2}$ concentration in 2012 (A) and 2013 (B). The arrows indicate the days on which biological sampling was performed. The dotted lines refer to the days without measurement of air pollutants. doi:10.1371/journal.pone.0096524.g001

urban area of Calcutta [44], which was higher than that found in those living in rural area $(0.22 \%$ vs $0.17 \%)$. Children of a similar age to those in our study were included in a study on genotoxicity of air pollutants generated by biomass burning [47], which found a significant difference in MN frequency in oral cells between children exposed to high PM2.5 concentration and those living in a control area with a lower PM2.5 concentration $(0.12 \%$ vs $0.02 \%$ in children under 7 years of age). A MN frequency similar to, or higher than, that observed in our study was reported in some studies carried out in Eastern Europe, as revised by Holland et al. [36].

According to a wide dataset which includes adults and children, a MN frequency interval of between $0.03 \%$ and $0.17 \%$ can be considered as a range of spontaneous $\mathrm{MN}$ frequency in buccal exfoliated cells of "unexposed" children [48]. Other authors have reported a range of $0.05-0.08 \%$ as the baseline $\mathrm{MN}$ frequency in exfoliated cells in healthy people [46]. Therefore, the mean MN frequency of $0.29 \%$ found in our study is about two-three-fold higher than that considered as a "reference" value for children of this age.

The MN frequency did not vary according to sex, age, parental education and all the variables investigated through the questionnaire. A weak, though statistically significant, association of MN frequency with concentration of air pollutants in the week preceding the buccal mucosa cell collection, but not on the same day and in the second or third week before sampling, was found. These results are partially in agreement with findings from previous studies comparing people at different exposure levels to air pollutants, which showed that industrial or urban air pollutants had a genotoxic effect on mucosa cells $[44,47,49]$. It should be pointed out, however, that the concentration of PM10, PM2.5 and $\mathrm{NO}_{2}$ was high throughout the study period, and always above the EU proposed limits for daily levels. The range of variation of pollutant concentration may therefore have been too narrow to determine a substantial change in MN frequency in the children. Alternatively, a threshold instead of a dose-response mechanism 


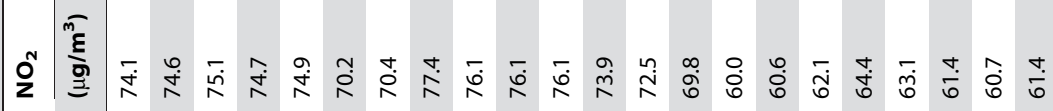

帘

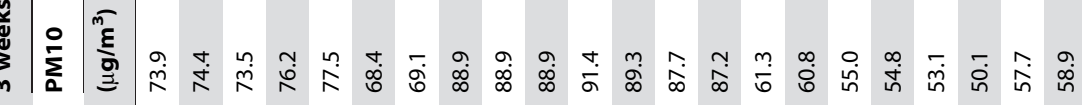

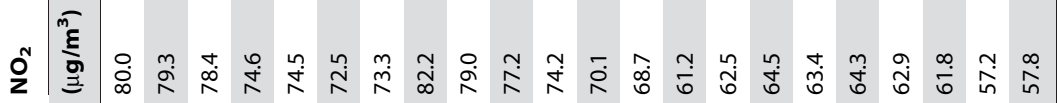

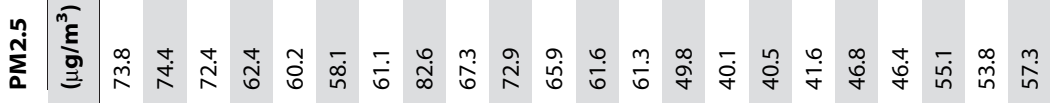
|

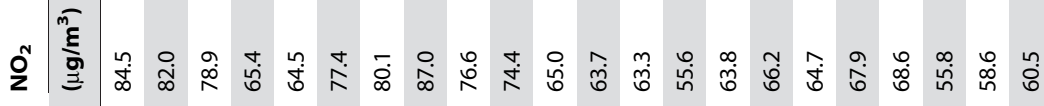

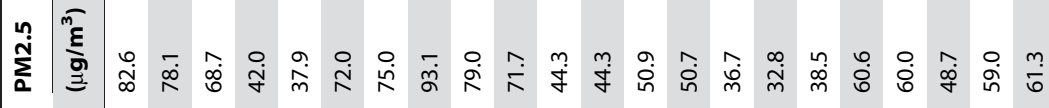
ते 嵅

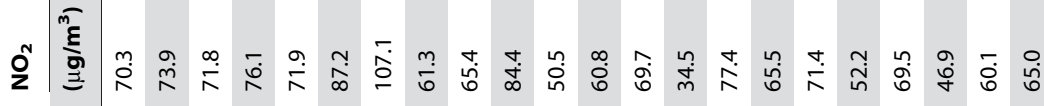

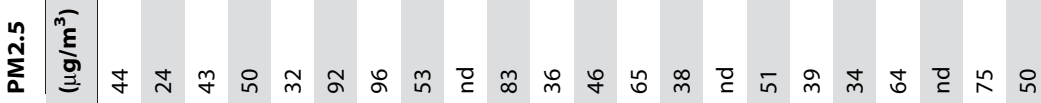
흥

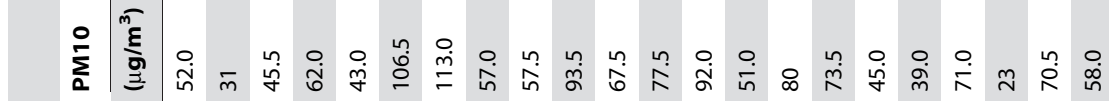

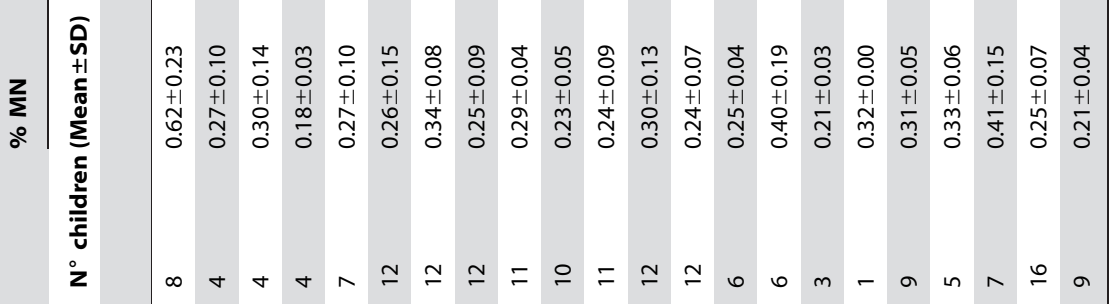
 


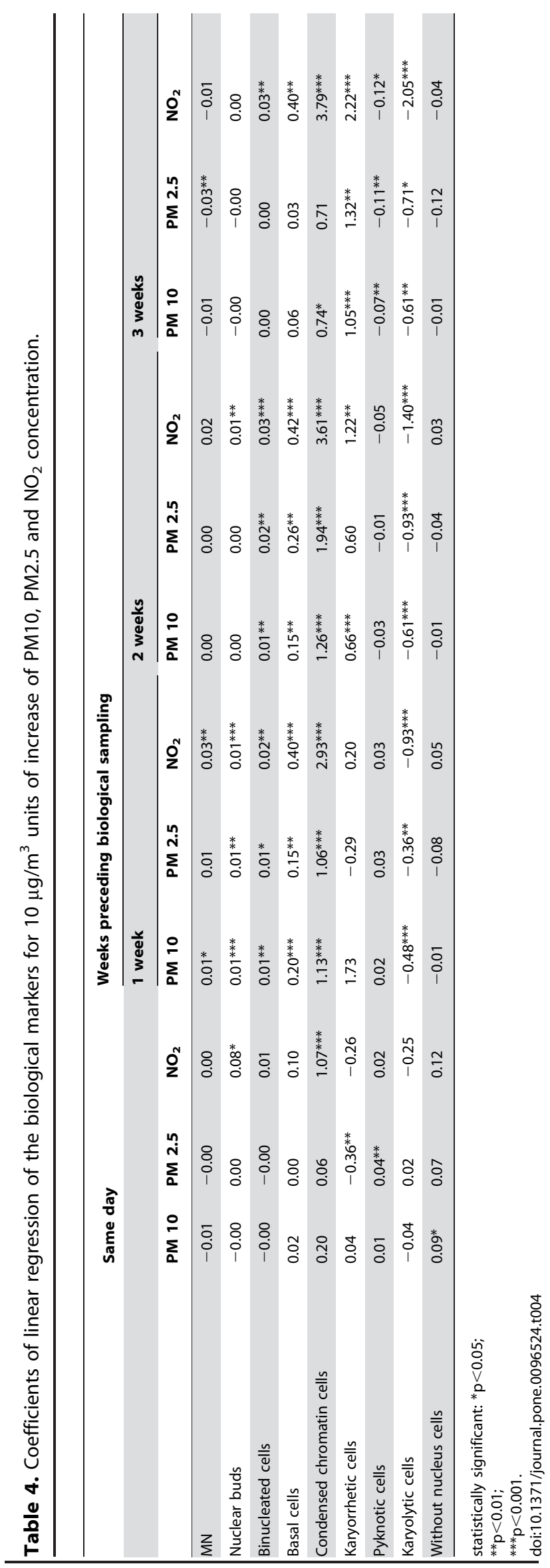

may be proposed, so similar genotoxic effects on children's buccal mucosa cells may have been produced by air pollutant values above a defined level. Lastly, the role of confounding factors, such as children's diet, physical activity and others, which was not investigated in our study, cannot be excluded. Indeed, some studies have observed an association between MN frequency in buccal mucosa cells and diet (e.g. fruit consumption, supplementation with $\mathrm{B}$ vitamins or antioxidants) and some specific behaviours, such as smoking habit, intake of alcohol, and betel quid chewing [21,37,48,51,52].

Other nuclear anomalies apart from MN were associated with the PM10, PM2.5 and $\mathrm{NO}_{2}$ concentration, particularly during the week preceding exfoliated cells sampling confirming findings of $\mathrm{MN}$ analysis on the possible effects of air pollutant exposure. However, the biological significance of these biomarkers in exfoliated oral cells is still unclear. Some nuclear anomalies, as buds, could be the result of genotoxic damage but these events are also associated with natural degenerative processes in these shortlived cells $[53,54]$. The frequency of binucleated cells was related to air pollutants concentration too. This parameter is primarily an indicator of cytotoxicity because of failures in cell division. Although these findings should be considered with caution because of paucity of data on the relationship between these biomarkers and air pollutants levels, overall they suggest that air pollution exposure may induce both genotoxic and cytotoxic damage in buccal mucosa cells of children. This observation strengthens the need to investigate these additional biomarkers of DNA damage together with $\mathrm{MN}$ for a more comprehensive evaluation of these issues.

This study has various strengths. First, the number of subjects recruited (181 children) is relatively high compared to previous studies of MN frequency in oral cells, particularly in this age group.

Second, it is unlikely that other important factors biased our results: there is no major industrial exposure in the area and few children could have been exposed to indoor pollution sources, including passive smoking at home, according to data collected via the questionnaire. Furthermore, the inclusion and exclusion criteria, e.g. residence in town, born to European parents, no malignant tumours, no radiotherapy or chemotherapy in the previous 12 months, no X-ray exposure in the three months before buccal cell collection, allowed us to rule out a possible role of other mutagenic factors.

Third, the collection of exfoliated buccal cells during two consecutive winter seasons (2012 and 2013) provided information on two periods characterized by similar environmental conditions and it showed consistent results, with no substantial difference in $\mathrm{MN}$ frequency in the two years.

Lastly, 4000 cells per child were scored for assessing MN frequency, representing a very high number of observations, higher than normally performed in current practice, in order to reduce the variability of the estimate, as suggested by Ceppi et al. [37].

This study has some limitations, however, mainly the lack of a control group of subjects living in a less polluted area or another collection of biological samples from the same or similar children in a period with lower airborne pollutant levels, for evaluating the role of spatial or seasonal differences in influencing MN frequency in buccal mucosa cells. Differences between more and less polluted areas have been found in some research [47] and seasonal differences in air pollution composition could be relevant for genotoxic damage, such as the summer increase of ozone concentration [46]. Nevertheless, this study was designed to assess MN frequency in a sufficiently large sample of children regularly 
exposed to high levels of air genotoxic pollutants (PM and $\mathrm{PAH}$ ), and not seasonal differences. We are, however, planning to extend the research to summer months and to children living in less polluted areas.

Only one sampling of oral cells was performed for each child, so the intra-individual variability of this early effect biomarker was not evaluated. The use of only one effect measure does not cause an important bias, however, because it reflects the mean exposure of the three preceding weeks, when the climate situation had not substantially changed. On the other hand, previous studies which found an association between this biomarker and air pollution also used a single measure of effect $[31,44,47,49,50,55,56]$.

$\mathrm{MN}$ are a marker of early biological effect able to detect both clastogens and aneuploidy-inducing chemicals [18]. They are formed from acentric chromosomal fragments or whole chromosomes that are not included in the main daughter nuclei during nuclear division and their induction therefore reflects clastogenic and/or aneugenic events. They represent stable cytogenetic alterations which are the result of recent exposure of buccal mucosa cells, in a rapidly dividing tissue $[18,28]$. These cells are short-lived and they are the first barrier for substances introduced into the body by inhalation or ingestion and may be an excellent target tissue for detecting early genotoxic effects induced by mutagenic airborne compounds. Their use can, therefore, be proposed for assessing exposure to airborne mutagens, especially

\section{References}

1. WHO (2006) Air Quality Guidelines. Global Update 2005. World Health Organization Office for Europe, Copenhagen, Denmark.

2. WHO (2007) Children's health and the environment in Europe: a baseline assessment. World Health Organization Regional Office for Europe, Copenhagen, Denmark.

3. EAA (2012) Air Quality in Europe 2011. European Environment Agency, Technical report No 4/2012.

4. Pope CA 3rd, Burnett RT, Thun MJ, Calle EE, Krewski D, et al. (2002) Lung cancer, cardiopulmonary mortality, and long-term exposure to fine particulate air pollution. JAMA 287(9):1132-1141.

5. ERS (2010) Air quality and health. European Respiratory Society. Lausanne, Switzerland.

6. Janssen NA, Fischer P, Marra M, Ameling C, Cassee FR (2013) Short-term effects of PM2.5, PM10 and PM2.5-10 on daily mortality in the Netherlands. Sci Total Environ 463-464: 20-26.

7. Raaschou-Nielsen O, Andersen ZJ, Beelen R, Samoli E, Stafoggia M, et al. (2013) Air pollution and lung cancer incidence in 17 European cohorts: prospective analyses from the European Study of Cohorts for Air Pollution Effects (ESCAPE). Lancet Oncol 14: 813-822.

8. Shah ASV, Langrish JP, Nair H, McAllister DA, Hunter AL, et al. (2013) Global association of air pollution and heart failure: a systematic review and metaanalysis. Lancet 382: 1039-1048.

9. Sørensen M, Autrup H, Møller P, Hertel O, Jensen SS, et al. (2003) Linking exposure to environmental pollutants with biological effects. Mutat Res 544: $255-271$.

10. Lewtas J (2007) Air pollution combustion emissions: characterization of causative agents and mechanisms associated with cancer, reproductive, and cardiovascular effects. Mutat Res 636: 95-133.

11. Claxton LD, Woodall GM Jr (2007) A review of the mutagenicity and rodent carcinogenicity of ambient air. Mutat Res 636: 36-94.

12. Møller P, Folkmann JK, Forchhammer L, Bräuner EV, Danielsen PH, et al. (2008) Air pollution, oxidative damage to DNA, and carcinogenesis. Cancer Lett 266: 84-97.

13. Monarca S, Crebelli R, Feretti D, Zanardini A, Fuselli S, et al. (1997) Mutagens and carcinogens in size-classified air particulates of a northern Italian town. Sci Total Environ 205: 137-144.

14. Monarca S, Feretti D, Zanardini A, Falistocco E, Nardi G (1999) Monitoring of mutagens in urban air samples. Mutat Res 426: 189-192.

15. Claxton LD, Matthews PP, Warren SH (2004) The genotoxicity of ambient outdoor air, a review: Salmonella mutagenicity. Mutat Res 567: 347-399.

16. Traversi D, Degan R, De Marco R, Gilli G, Pignata C, et al. (2009) Mutagenic properties of PM2.5 urban pollution in the northern Italy: the nitro-compounds contribution. Environ Int 35: 905-910.

17. de Brito KC, de Lemos CT, Rocha JA, Mielli AC, Matzenbacher C, et al. (2013) Comparative genotoxicity of airborne particulate matter (PM2.5) using Salmonella, plants and mammalian cells. Ecotoxicol Environ Saf 94: 14-20.

18. Kirsch-Volders M, Plas G, Elhajouji A, Lukamowicz M, Gonzalez L, et al. (2011) The in vitro MN assay in 2011: origin and fate, biological significance, in the paediatric population as they are easy to collect, considering also the strong correlation of MN frequency in these cells and in lymphocytes, which have been shown to be related to the subsequent risk of developing cancer $[37,48]$.

Brescia is a highly industrialized area with a high level of motor vehicle traffic. It is located in the Po Valley, one of the most highly polluted areas of Europe, where the concentrations of PM10, PM2.5 and NOx are usually above the EU reference values for many days of the year, as in the two years of this study (2012 and 2013), similar to those found in other towns and cities in the Po Valley [3].

In conclusion, this study shows that children living in a town with high levels of air pollutants in a Western country have a high level of $\mathrm{MN}$ in buccal mucosa cells, confirming previous findings of a mutagenic effect of urban air pollution on human beings.

\section{Acknowledgments}

We wish to thank the Brescia Municipality for its logistic support and the school personnel and all children and parents involved in the research.

\section{Author Contributions}

Conceived and designed the experiments: EC DF FD UG. Performed the experiments: EG DF GCVV IZ CZ. Analyzed the data: RML MC RL FD. Wrote the paper: EC DF FD UG.

protocols, high throughput methodologies and toxicological relevance. Arch Toxicol 85: 873-899. doi:10.1007/s00204-011-0691-4

19. Tolbert PE, Shy CM, Allen JW (1992) Micronuclei and other nuclear anomalies in buccal smears: methods development. Mutat Res 271: 69-77.

20. Fenech M, Crott JW (2002) Micronuclei, nucleoplasmic bridges and nuclear buds induced in folic acid deficient human lymphocytes - evidence for breakage - fusion-bridge cycles in the cytokinesis-block micronucleus assay. Mutat Res 504: 131-136

21. Holland N, Bolognesi C, Kirsch-Volders M, Bonassi S, Zeiger E, et al. (2008) The micronucleus assay in human buccal cells as a tool for biomonitoring DNA damage: the HUMN project perspective on current status and knowledge gaps. Mutat Res 659: 93-108.

22. Thomas P, Holland N, Bolognesi C, Kirsch-Volders M, Bonassi S, et al. (2009) Buccal micronucleus cytome assay. Nat Protoc 4(6):825-837.

23. Hagmar L, Brøgger A, Hansteen IL, Heim S, Högstedt B, et al. (1994) Cancer risk in humans predicted by increased levels of chromosomal aberrations in lymphocytes: Nordic study group on the health risk of chromosome damage. Cancer Res 4(11):2919-2922.

24. Bonassi S, Abbondandolo A, Camurri L, Dal Prá L, De Ferrari M, et al. (1995) Are chromosome aberrations in circulating lymphocytes predictive of future cancer onset in humans? Preliminary results of an Italian cohort study. Cancer Genet Cytogenet 79(2):133-135.

25. Bonassi S, Znaor A, Ceppi M, Lando C, Chang WP, et al. (2007) An increased micronucleus frequency in peripheral blood lymphocytes predicts the risk of cancer in humans. Carcinogenesis 28(3):625-631.

26. Bonassi S, El-Zein R, Bolognesi C, Fenech M (2011) Micronuclei frequency in peripheral blood lymphocytes and cancer risk: evidence from human studies. Mutagenesis 26(1):93-100.

27. Coronas MV, Pereira TS, Rocha JA, Lemos AT, Fachel JM, et al. (2009) Genetic biomonitoring of an urban population exposed to mutagenic airborne pollutants. Environ Int 35(7):1023-1029.

28. Kashyap B, Reddy PS (2012) Micronuclei assay of exfoliated oral buccal cells: means to assess the nuclear abnormalities in different diseases. J Cancer Res Ther 8(2):184-191.

29. Samanta S, Dey P (2012) Micronucleus and its applications. Diagn Cytopathol 40: 84-90.

30. Bolognesi C, Merlo F, Rabboni R, Valerio F, Abbondandolo A (1997) Cytogenetic biomonitoring in traffic police workers: micronucleus test in peripheral blood lymphocytes. Environ Mol Mutagen 30: 396-402.

31. Maffei F, Hrelia P, Angelini S, Carbone F, Cantelli Forti G, et al. (2005) Effects of environmental benzene: Micronucleus frequencies and haematological values in traffic police working in an urban area. Mutat Res 583: 1-11.

32. Cavallo D, Ursini CL, Carelli G, Iavicoli I, Ciervo A, et al. (2006) Occupational exposure in airport personnel: characterization and evaluation of genotoxic and oxidative effects. Toxicology 223: 26-35.

33. Huen K, Gunn L, Duramad P, Jeng M, Scalf R, et al. (2006) Application of a geographic information system to explore associations between air pollution and 
micronucleus frequencies in African American children and adults. Environ Mol Mutagen 47(4):236-246.

34. Pedersen M, Vinzents P, Petersen JH, Kleinjans JC, Plas G, et al. (2006) Cytogenetic effects in children and mothers exposed to air pollution assessed by the frequency of micronuclei and fluorescence in situ hybridization (FISH): a family pilot study in the Czech Republic. Mutat Res 608: 112-120.

35. Tovalin H, Valverde M, Morandi MT, Blanco S, Whitehead L, et al. (2006) DNA damage in outdoor workers occupationally exposed to environmental air pollutants. Occup Environ Med 63: 230-236.

36. Holland N, Fucic A, Merlo DF, Sram R, Kirsch-Volders M (2011) Micronuclei in neonates and children: effects of environmental, genetic, demographic and disease variables. Mutagenesis 26: 51-56.

37. Ceppi M, Biasotti B, Fenech M, Bonassi S (2010) Human population studies with the exfoliated buccal micronucleus assay: statistical and epidemiological issues. Mutat Res 705(1):11-19.

38. Desai SS, Ghaisas SD, Jakhi SD, Bhide SV (1996) Cytogenetic damage in exfoliated oral mucosal cells and circulating lymphocytes of patients suffering from precancerous oral lesions. Cancer Lett 109: 9-14.

39. Landrigan PJ, Kimmel CA, Correa A, Eskenazi B (2004) Children's health and the environment: public health issues and challenges for risk assessment. Environ Health Perspect 112(2):257-265.

40. WHO (2005) Effects of air pollution on children's health and development. World Health Organization Regional Office for Europe, Copenhagen, Denmark.

41. Bateson TF, Schwartz J (2008) Children's response to air pollutants. J Toxicol Environ Health A 71(3):238-243.

42. Grigg J (2009) Particulate matter exposure in children: relevance to chronic obstructive pulmonary disease. Proc Am Thorac Soc 6(7):564-569.

43. Wild CP, Kleinjans J (2003) Children and increased susceptibility to environmental carcinogens: evidence or empathy? Cancer Epidemiol Biomarkers Prev 12(12):1389-1394.

44. Lahiri T, Roy S, Basu C, Ganguly S, Ray MR, et al. (2000) Air pollution in Calcutta elicits adverse pulmonary reaction in children. Indian J Med Res 112: 21-26.

45. Montero R, Serrano L, Dávila V, Segura Y, Arrieta A, et al. (2003) Metabolic polymorphisms and the micronucleus frequency in buccal epithelium of adolescents living in an urban environment. Environ Mol Mutagen 42: 216-222.
46. Chen C, Arjomandi M, Qin H, Balmes J, Tager I, et al. (2006) Cytogenetic damage in buccal epithelia and peripheral lymphocytes of young healthy individuals exposed to ozone. Mutagenesis 21(2):131-137.

47. Sisenando HA, Batistuzzo de Medeiros SR, Artaxo P, Saldiva PH, Hacon Sde S (2012) Micronucleus frequency in children exposed to biomass burning in the Brazilian Legal Amazon region: a control case study. BMC Oral Health 12: 6. doi:10.1186/1472-6831-12-6

48. Bonassi S, Coskun E, Ceppi M, Lando C, Bolognesi C, et al. (2011) The HUman MicroNucleus project on eXfoLiated buccal cells (HUMN(XL)): the role of life-style, host factors, occupational exposures, health status, and assay protocol. Mutat Res 728(3):88-97.

49. Karahalil B, Karakaya AE, Burgaz S (1999) The micronucleus assay in exfoliated buccal cells: application to occupational exposure to polycyclic aromatic hydrocarbons. Mutat Res 442(1):29-35.

50. Rossnerova A, Spatova M, Pastorkova A, Tabashidze N, Veleminsky M Jr, et al. (2011) Micronuclei levels in mothers and their newborns from regions with different types of air pollution. Mutat Res 715: 72-78.

51. Mondal NK, Ghosh S, Ray MR (2011) Micronucleus formation and DNA damage in buccal epithelial cells of Indian street boys addicted to gasp 'Golden glue'. Mutat Res 721: 178-183.

52. Thomas P, Wu J, Dhillon V, Fenech M (2011) Effect of dietary intervention on human micronucleus frequency in lymphocytes and buccal cells. Mutagenesis 26: $69-76$.

53. Nersesyan AK (2005) Nuclear buds in exfoliated human cells. Letter to the Editor. Mutat Res 588: 64-68.

54. Cerqueira EMM, Gomes-Filho IS, Trindade S, Lopes MA, Passos JS, et al. (2004) Genetic damage in exfoliated cells from oral mucosa of individuals exposed to X-rays during panoramic dental radiographies. Mutat Res 562: 111117.

55. Neri M, Ugolini D, Bonassi S, Fucic A, Holland N, et al. (2006) Children's exposure to environmental pollutants and biomarkers of genetic damage. II. Results of a comprehensive literature search and meta-analysis. Mutat Res 612: 14-39.

56. Pedersen M, Wichmann J, Autrup H, Dang DA, Decordier I, et al. (2009) Increased micronuclei and bulky DNA adducts in cord blood after maternal exposures to traffic-related air pollution. Environ Res 109: 1012-1020. 